\title{
Multimodal Rehabilitation in Geriatric Emergency Surgery
}

\section{Jorge Pereira', Mihai Paduraru²}

${ }^{1}$ General Surgery Department, Hospital Centre Tondala-Viseu, Portugal

${ }^{2}$ Department of Emergency Surgery, Milton Keynes University Hospital, United Kingdom

Corresponding author:

Jorge Pereira, MD

General Surgery Department

Hospital Centre Tondala-Viseu

Portugal

E-mail: docjota@netcabo.pt

\section{Rezumat}

Reabilitarea multimodadă în chirurgia geriatrică de urgență

Introducere: Includerea în practica clinică perioperatorie a reabilitării multimodale reprezintă o evoluția anticipată a unui concept inițiat în ultimele decenii, denumit inițial "fast track" şi cunoscut astăzi ca o efectivă modalitate de recuperare postoperatorie intensificată după interventiile chirurgicale (ERAS Enhanced Recovery After Surgery). Acest concept se referă la utilizarea unor protocoale standardizate de îngrijire perioperatorie, susținute de evidența ştiințifică actuală şi vizează reducerea traumei şi stresului chirurgical. Deşi aplicarea unor astfel de protocoale pentru chirurgia de urgență oferă rezultate favorabile, utilizarea ERAS în contextul chirurgiei geriatrice de urgență nu a fost amplu aplicată şi nu există astăzi suficiente studii care să susțină utilizarea acestuia. $\mathrm{Cu}$ toate acestea, ERAS ar putea contribui la îmbunătățirea rezultatelor la acest grup de pacienți, ținând cont de nivele de morbiditate şi mortalitate înalte în acest teritoriu.

Material şi Metodă: În vederea pregătirii unei sesiuni din cadrul celui de-al 18-lea Congres European de Traumă şi Chirugie de Urgență ce a avut loc în Bucureşti (Mai 2017), autorii au efectuat o revizie de literatură medico-chirurgială folosind termenii 'ERAS', 'fast-track', 'emergency surgery', 'emergency medicine', 'multimodal rehabilitation', and 'elderly patient', pentru a colecta evidența ştiințifică suficientă cu scopul de a analiza aplicabilitatea ERAS cu succes şi a îmbunătăți rezultatele postoperatorii la pacienții geriatrici în chirurgia de urgență.

Concluzie: Managementul chirurgical de urgență al pacienților vârstnici este asociat cu înalte nivele de morbiditate şi mortalitate, existând opțiuni moderne de îmbunătătire a rezultatelor. Un 
program de reabilitare multimodală pare a fi un bun model de lucru pentru atingerea acestor obiective.

Cuvinte cheie: reabilitare multimodală, pacient în vârstă, chirurgie de urgență, fast-track

\begin{abstract}
Introduction: Perioperative application of multimodal rehabilitation pathways represents the anticipated evolution of a concept that has arisen in recent decades, initially named fast-track surgery and known today as enhanced recovery after surgery (ERAS). This concept refers to the use of standardised perioperative care protocols that are supported by evidence-based medicine and aim to reduce surgical trauma and stress. Although application of such protocols to emergency surgery has produced favourable results, the use of ERAS in the geriatric emergency surgery setting has not been widely applied, and no studies have produced results that support its use in this setting. However, ERAS could help improve outcomes in this group of patients, who already have high surgical morbidity and mortality rates.

Material and Methods: In preparation for a lecture presented at the $18^{\text {th }}$ European Congress of Trauma and Emergency Surgery (Bucharest, May 2017), the authors performed a literature search using the terms 'ERAS', 'fast-track', 'emergency surgery', 'emergency medicine', 'multimodal rehabilitation', and 'elderly patient' to gather scientific evidence with which to present suggestions in support of their opinion that ERAS could be applied successfully to improve postoperative outcomes for geriatric emergency patients.

Conclusion: Urgent surgical treatment of elderly patients is associated with morbidity and mortality rates higher than those of younger patients, and there is room for improvement. A multimodal rehabilitation program seems to be a good working model for achieving this goal.
\end{abstract}

Key words: multimodal rehabilitation, elderly patient, emergency surgery, fast-track

\section{Introduction}

Perioperative application of multimodal rehabilitation (MR) models represents the anticipated evolution of a concept that has arisen in recent decades, initially called fast-track surgery and known today as enhanced recovery after surgery (ERAS) (1,2). This concept refers to the use of standardised perioperative care protocols supported by evidence-based medicine that aim to reduce surgical trauma and stress. The use of ERAS protocols has resulted in reductions in the postoperative morbidity rate, more rapid recovery, and a decreased length of hospital stay with obvious economic, clinical, and managerial benefits. The first trials and publications related to ERAS involved the use of protocols in elective surgery, mostly colorectal $(1,2)$. The studies showed that these protocols were feasible and reduced the length of hospital stay without increasing morbidity.

Despite the inherent difficulties in the applicability of MR protocols to certain settings in which some preoperative variables cannot be enhanced (e.g., emergency surgery), such protocols have still been attempted with the aim of reproducing the same results obtained in elective surgery. Studies have shown that MR protocols were not only feasible but also led to improvements in outcomes (3-7).

Initial studies involved only cohorts of patients without specification of age groups. Several authors sought to determine whether the results would be reproducible in patients 
of advanced age. Subsequent studies showed that the use of MR protocols was also favourable in this particular group of patients, who obtained similar improvements as those in younger patients $(8,9)$.

Elderly patients have particular characteristics. Their surgical mortality and morbidity rates are higher than in younger patients. These statistics worsen when the emergency surgery factor is considered (10-13). This is not only due to the combination of specific variables that characterise the disease itself but also to patient associated illnesses, cognitive and physical status, and social and family situation. Therefore, the implementation of a MR protocol in the emergency surgery setting in elderly patients might reverse the poor outcomes usually obtained (14). These issues have particular importance today, with the increase in the average life expectancy and subsequent exponential growth of the elderly population and in turn, the number of elderly patient accessing emergency departments. (EDs).

\section{Care Pathways}

The main goal of MR protocols is reduction of morbidity and mortality. Experience has shown that surgical cure alone of an illness is inadequate, since morbidity may increase due to other variables in elderly patients. Hence, rapid recovery and rehabilitation should be started as soon as possible $(15,16)$.

Given the lack of studies specifically focusing on Geriatric Emergency Surgery (GES), it is necessary to gather evidence from studies focused on MR and elderly, MR and emergency surgery, Guidelines on Surgical Care of elderly patients and adapt them to this particular context, while acknowledging the needs of the individual patient circumstances. The need for a multidisciplinary team is essential. A joint approach involving medical, social, managerial, familial, and other areas of expertise is necessary to effectively provide the required care $(14,17,18)$.

There are five main time points of possible action in an MR protocol for GES patients: during the pre-hospital phase, during the stay in the $\mathrm{ED}$, in the operating room, during postoperative hospitalisation, and after hospital discharge. At each stage, a different but dedicated group of professionals should contain activities that can be delivered in bundles in order to facilitate standardisation of teaching and learning and evaluation of the outcomes (19).

\section{Pre-hospital Phase}

The pre-hospital personnel should gather important data in relation to the patient. This information will be compiled with data from Social Services and the patient's medical history (2,16-19). Some important aspects that may serve to identify some "hidden threats" during this initial assessment are outlined below:

- Signs of physical or emotional isolation can sometimes be associated with negligence or violence by family members or caregivers. This aspect must be considered to avoid repeated emergency department consultation. It may also be important to evaluate the patient's mental status and its possible progression during the current acute illness.

- Economic disparities and poverty may be associated with malnutrition and poor control of chronic diseases because of lack of medication.

- Polypharmacy has been directly linked to postoperative morbidity in several studies. Polypharmacy is often associated with drug repetition, which leads to drug overdose and morbidity.

- Assessment of the patient's physical function and cognitive status prior to the development of an acute disease is critical. This assessment will influence decisionmaking regarding invasive treatments such as surgery, but it is also important because ongoing physical and mental deterioration is associated with morbidity and mortality. The development of delirium is often associated with postoperative mortality. Physical dysfunction and disability contribute to the risk of falls. 
- Malnutrition alone is a risk factor for morbidity and mortality. It is important to stress that the pre-hospital staff can be useful beyond their usual functions and that these aspects should be introduced into their basic training. These staff members must be provided with tools to quickly identify elderly patients at risk of adverse effects and report these findings. Pre-hospital staff could serve as public health stewards (19), seizing the opportunity of their privileged position in the health care chain.

\section{Emergency Department}

During the last several years, researchers have been studying the optimal characteristics of the $\mathrm{ED}$, where assessment and management of these elderly patients takes place $(2,17,18)$. Beyond the provision of readiness of a multidisciplinary team, the ED must provide an environment adapted to elderly patients to facilitate information collection and reduce psychological and physical stress. This eases the integration of elderly patient and prevents development of cognitive and/or physical dysfunction. Some authors have already mentioned the need for a specialised ED specifically designed for the care of elderly rather than a dedicated team in the general ED.

An overall patient assessment, not including a diagnostic evaluation, is required. A Comprehensive Geriatric Assessment (CGA), involves careful observation of several parameters to obtain a physiological picture of the patient and infer the risk of developing adverse effects at multiple levels is the ideal $(2,19-23)$. This initial evaluation will allow for action on modifiable variables, establishment of a prehabilitation plan (or preoperative rehabilitation), and evaluation of the patient's operative risk. Its main parameters are shown in Table 1 (20). Some of these parameters are common to the preoperative evaluation of all patients, but at least one is specific to this age group: frailty $(20,24,25)$. The key question when discussing the care of geriatric patients has always been the definition of elderly (12). For many years in the medical literature, the definition of elderly has been $\geq 65$ years, and most studies are based on this definition. However, the average life expectancy has been increasing over the past several decades, and the characteristics of older individuals have been changing in relation to improved quality of life. Hence, the definition of elderly has been called into dispute. A way to solve this problem is to use a physiological definition that does not depend exclusively on age but on the biological modifications of this age group.

Frailty is a concept that could potentially resolve this issue. Frailty is defined as a syndrome associated with vulnerability resulting from the age-related accumulation of deficiencies in different physiological systems $(24,25)$. Evaluation of frailty is mandatory in the CGA.

In several studies and medical settings, use of the CGA has been shown to reduce mortality, reduce physical deterioration, improve hospital discharge, and be cost-effective. Its main benefit is reportedly a reduction in delirium and loss of function (both physical and mental) in the postoperative period (20-22).

Still, in the ED, more effort is necessary to achieve an early diagnosis, and timely treatment is important. Rapid resuscitation, medical optimisation, and the liberal use of diagnostic resources are critical $(12,15)$.

The decision-making process must take a wide range of options into account, including minimally invasive interventions. Use of these less invasive strategies could be the difference between an adequate functional recovery and a cure that leaves the patient dysfunctional and unable to resume his or her preoperative status (12). Several nonsurgical options are currently available that may represent alternative treatments for these older and less tolerant surgical patients. For example, cholecystostomy may be an alternative to cholecystectomy. It may not be a definitive treatment, but it will resolve the acute situation with less harm to the patient. Therefore, the realistic prediction of risk is important to ensure that a viable option is offered to the patient. The patient's wishes must be fully respected when any decision is made, especially end-of-life decisions $(16,26)$. This is 
Table 1. Minimum components of pre-operative geriatric comprehensive assessment adapted from BGS (20) and Griffiths et al (27)

\begin{tabular}{|c|c|c|}
\hline Domain & Item & Tool \\
\hline Medical & $\begin{array}{l}\text { Co-morbidity/severity: } \\
\text { - } \quad \text { Cardiovascular } \\
\text { - } \quad \text { Respiratory } \\
\text { - } \quad \text { Haematological } \\
\text { - } \quad \text { Renal } \\
\text { - } \quad \text { Musculoskeletal } \\
\text { Previous anaesthesia } \\
\text { Anaesthesia specific } \\
\text { Alcohol intake } \\
\text { Nutritional status } \\
\text { Allergy history }\end{array}$ & $\begin{array}{l}\text { Vital signs, ECG, CPET } \\
\text { Sp02, respiratory function tests } \\
\text { Full blood count } \\
\text { Urea, electrolytes, eGFR } \\
\text { Inquiry } \\
\text { Airway, dentition } \\
\text { Weight, BMI, Albumin }\end{array}$ \\
\hline Medication & $\begin{array}{l}\text { Review } \\
\text { Anticoagulation }\end{array}$ & $\begin{array}{l}\text { Pre-operative assessment } \\
\text { Coagulation screen }\end{array}$ \\
\hline Cognitive & $\begin{array}{l}\text { Mental capacity } \\
\text { Decision-making capacity } \\
\text { Communication } \\
\text { Risk factors for delirium } \\
\text { Fears }\end{array}$ & $\begin{array}{l}\text { Ask the carers } \\
\text { Abbreviated mental test score } \\
\text { Speech, hearing } \\
\text { Pre-operative assessment } \\
\text { Appease }\end{array}$ \\
\hline Physical & $\begin{array}{l}\text { Basic everyday activities } \\
\text { Gait and balance } \\
\text { Mobility }\end{array}$ & $\begin{array}{l}\text { Walk } \\
\text { Ask carers }\end{array}$ \\
\hline Aids & $\begin{array}{l}\text { Visual } \\
\text { Hearing } \\
\text { Mobility } \\
\text { Dentures }\end{array}$ & $\begin{array}{l}\text { Glasses } \\
\text { Hearing aids } \\
\text { Walking stick, wheelchair }\end{array}$ \\
\hline Score & $\begin{array}{l}\text { Pathology-specific } \\
\text { Frailty }\end{array}$ & $\begin{array}{l}\text { e. g. Nottingham hip fracture score } \\
\text { Pre-operative assessment }\end{array}$ \\
\hline Social/Environment & $\begin{array}{l}\text { Family support } \\
\text { Social network (daytime activities, friends, etc.) } \\
\text { Home comfort } \\
\text { Transport facilities } \\
\text { Accessibility to resources }\end{array}$ & Ask carers and social workers \\
\hline
\end{tabular}

BGS, British Geriatric Society; ECG, electrocardiogram; CPET, cardiopulmonary exercise test; Sp02, haemoglobin oxygen saturation; eGFR, estimated glomerular filtration rate; BMI, body mass index

true in circumstances involving terminal diseases and when the patient wishes to refrain from surgical treatment. Palliative care may be an option, and involvement of the patient and family members or caregivers in the decisionmaking process is mandatory. This not only creates bonds of accountability but also eases the surgeon's burden.

\section{Operating Room}

After the decision to operate has been made, the perioperative period is crucial for delivering the correct surgical treatment and ensuring that the anaesthesia is adapted to the specific problems of elderly patients (27). As always, monitoring should be optimal; in these particular cases, however, the clinician must be especially attentive to changes associated with the patient's age and medical history. Cardiac, respiratory, and renal pathologies, among others, should be given detailed attention, and the attitudes taken should be directed to specific goals including reduction of surgical stress, use of appropriate anaesthetic drugs, correction of physiological anomalies during the intervention, and tight control of temperature to avoid hypothermia, among others. An experienced anaesthetist, preferably a consultant with expertise in these types of circumstances, should be responsible for the perioperative care $(27,28)$.

The surgical intervention should be performed in a timely manner after achieving an accurate and expedited diagnosis. Loss of time 
can be fatal, especially in elderly patients. Additionally, a consultant surgeon with wide experience in emergency surgery should be considered for performance of the intervention $(3,11,12,16,27)$.

Table 2 shows the recommended amendments to the World Health Organization Surgical Safety Checklist for elderly patients aged $>75$ years $(27)$.

\section{Postoperative Period}

Surgical stress will lead to an imbalance in homeostasis in patients whose fragile condition may not allow for spontaneous restitution. These patients therefore require closer monitoring and more watchful and expeditious care. For this reason, the postoperative period for most elderly patients in the emergency setting should take place in a high-grade care unit intermediate or intensive care $(16,27)$. The surgeon in charge must decide which is best for each situation. Enlisting the help of specialists in treating elderly patients is also extremely important. The treatment and monitoring of many medical conditions will be much more appropriate in the hands of a geriatrician who is skilled in recognizing the signs and symptoms of these conditions, including cardiac, respiratory, urinary, and metabolic dysfunction. However, the surgeon's role is fundamental for early recognition of postoperative complications, such as anastomotic failure and haemorrhage. Early identification and prompt management of any of these situations may reduce mortality or sub-sequent physical and mental dysfunction. This team approach will help to avoid failure to rescue and provide proper and effective treatment to the patient (16,29-32).

In the postoperative period, it is also necessary to handle the patient's comorbidities while avoiding decompensation and dealing with polypharmacy. During this period, it is wise to establish a plan of action for discharge that ideally reduces the outpatient pharmacological burden and minimises the use of drugs associated with an increased risk of delirium and cognitive dysfunction. Physical rehabilitation also plays an important role in maintaining
Table 2. Recommended pre-operative amendments to the World Health Organisation Surgical Safety Checklist for patients above 75 years.

\section{Sign in: before induction}

Have vital signs been recorded (heart rate, blood pressure, heart rhythm, Sp02, temperature)?

Is the patient's resuscitation status known?

Does the patient have dentures?

Does the patient have any pre-operative pressure sores?

Has the site of any nerve block been confirmed and marked?

Time out: before incision

Have possible areas of pressure damage been padded?

What is the patient's haemoglobin concentration?

Does the patient have dentures? What is the patient's eGFR?

\section{Sign out: before leaving theatre}

What is the patient's core temperature?

What is the patient's haemoglobin concentration?

Have age-adjusted and renal function-adjusted doses of postoperative analgesia been prescribed?

Has a postoperative fluid plan been prescribed?

Can the patient be returned safely to a general care ward?

Sp02, haemoglobin oxygen saturation; eGFR, estimated glomerular filtration rate

the patient's autonomy and self-image and preventing delirium. This plan should include a way to ensure a smooth return home, avoiding abrupt changes in the environment and circadian cycle $(11,27)$.

Table 3 shows the steps of the Emergency Laparotomy Pathway Quality Improvement Care Bundle (ELPQuiC) (3). The ELPQuiC was devised by the National Health Service of the United Kingdom to standardise procedures and reduce the morbidity associated with urgent laparotomy. Although it was not created for elderly patients, it can be used as a model for such patients and provides a good summary of the perioperative period in the emergency surgery setting. The timing outlined in the ELPQuiC should be slightly more expeditious when treating elderly patients.

\section{Discharge Strategy}

It would seem that after discharge from the hospital, the patient should be ready to return to his or her life and function in society. Although this may be true for younger patients in most situations, it is not true for 
Table 3. ELPQuiC (Emergency Laparotomy Pathway Quality Improvement Care Bundle) steps from Quiney et al (3).

\begin{tabular}{|c|c|}
\hline $\begin{array}{l}\text { Early assessment } \\
\text { and resuscitation }\end{array}$ & $\begin{array}{l}\text { MEWS within } 30 \text { ' of arrival } \\
\text { Outreach review if MEWS } \\
\text { above } 3 \\
\text { Consultant surgical review } \\
\text { within } 30^{\prime} \text { of referral } \\
\text { Measure arterial lactate levels } \\
\text { Prompt fluid resuscitation }\end{array}$ \\
\hline Early antibiotics & $\begin{array}{l}\text { Within } 1 \text { hour if evidence of SIRS/Sepsis } \\
\text { Within } 3 \text { hours if intra-peritoneal soiling } \\
\text { suspected }\end{array}$ \\
\hline $\begin{array}{l}\text { Prompt diagnosis } \\
\text { and early surgery }\end{array}$ & $\begin{array}{l}\text { CT scan within } 2 \text { hours of booking and } \\
\text { report within } 1 \text { hour of scan } \\
\text { Priority in Theatre } \\
\text { Knife to skin within } 6 \text { hours of decision to } \\
\text { operate } \\
\text { Consultant surgeon and anaesthetist present }\end{array}$ \\
\hline $\begin{array}{l}\text { Goal directed } \\
\text { fluid therapy }\end{array}$ & $\begin{array}{l}\text { Goal directed fluid therapy using cardiac output } \\
\text { monitoring during surgery and for } 6 \text { hours } \\
\text { postoperatively }\end{array}$ \\
\hline $\begin{array}{l}\text { Postoperative } \\
\text { Intensive Care for all }\end{array}$ & $\begin{array}{l}\text { If no intensive care bed available, alternative } \\
\text { level } 2 \text { area }\end{array}$ \\
\hline
\end{tabular}

MEWS, Modified Early Warning Score; SIRS, Systemic Inflammatory

Response Syndrome; CT scan, Computed Tomography scan

elderly patients. Extensive preparations for discharge must first be performed $(27,28)$. As stated earlier, this requires planning and forethought. Additionally, the patient or his or her relatives and caregivers may need to alter their homes to create optimal conditions for receiving a patient with a liability that was not present before hospitalisation. Such alterations may be as simple as some type of physical restraint or assistance with moving, but they may also be more complex, as in patients with a colostomy. Therefore, there is often a transition period in which the caregivers and patient should be supported by a team that visits the home and manages some of these aspects (complex wounds, drains, bladder catheters, etc.). Some countries have specific inpatient units that offer this kind of integrated care. The patients remain in these convalescence units for the length of time necessary to ensure optimal recovery after hospital discharge $(19,21)$.

The patient should leave the hospital with all information regarding their hospitalisation, pathological condition, and surgical intervention. This information is necessary for health professionals who provide continuity of care to integrate it into their assessment and management of other disease circumstances.

Finally, the outpatient follow-up should not be neglected. Re-observation of patients until treatment consolidation is important not only for elderly patients but also for patients with various pathologies such as cancer.

\section{Present and Future}

MR or ERAS is well defined in certain areas and has been applied to the emergency setting with good results. In addition to clinical improvement, there also appear to be managerial advantages in its use $(1,2)$. Its application to elderly patients is possible $(8,9)$, and, as suggested in the present report, it can even be applied in an emergency environment (14). Several studies have shown reductions in the length of hospital stay, more effective discharge to home, and reductions in cognitive and physical dysfunction. However, the primary objectives remain reductions in the morbidity and mortality rates. Further studies that specifically target GES are needed to establish an evidence-based practice. Until then, it will be important to evaluate and classify the various methods of preoperative evaluation and verify their applicability in an emergency environment. Identification of one that suits this particular population is needed. It will also be important to find a tool for accurate risk calculation to define the optimal model of urgent surgical care for the elderly (12). Although such a model may not be applied to all patients, it would serve as a suitable way to address disease, physiologic dysfunction, and frailty. The goal is to reduce cognitive and physical dysfunction, allowing the patient to return to their previous place in society with body and mind restored $(11,12,14)$.

\section{Conclusions}

Urgent surgical treatment of elderly patients is associated with higher morbidity and mortality rates than those of younger patients, and there is room for improvement. An MR program 
seems to be a good working model for achieving this improvement.

\section{Acknowledgement}

We thank Angela Morben, DVM, ELS, from Edanz Group (www.edanzediting.com/ac) and Melanie Radcliff, BA (University Literature and Master Studies, Bristol University) for editing a draft of this manuscript.

\section{Authors' contributions}

Jorge Pereira - systematic revision, synthesis of the evidence, write de article.

Paduraru Mihai - synthesis of the evidence, review the article.

\section{References}

1. Kehlet $H$, Wilmore DW. Evidence-based surgical care and the evolution of fast-track surgery. Ann Surg. 2008;248(2):189-98. doi: 10.1097/SLA.0b013e31817f2c1a.

2. Kehlet $H$. Multimodal approach to control postoperative pathophysiology and rehabilitation. Br J Anaesth. 1997;78(5):606-17.

3. Quiney N, Aggarwal G, Scott M, Dickinson M. Survival After Emergency General Surgery: What can We Learn from Enhanced Recovery Programmes? World J Surg. 2016;40(6):1283-7. doi: 10.1007/s00268-016-3418-0.

4. Lohsiriwat V. Enhanced recovery after surgeryvsconventional care in emergency colorectal surgery. World J Gastroenterol. 2014;20(38): 13950-5. doi: 10.3748/wjg.v20.i38.13950.

5. Gonenc M, Dural A, Celik F, Akarsu C, Kocatas A, Kalayci M et al. Enhanced postoperative recovery pathways in emergency surgery: a randomised controlled clinical trial. Am J Surg. 2014;207(6):80714. doi: 10.1016/j.amjsurg.2013.07.025. Epub 2013 Oct 10.

6. Wisely JC, Barclay KL. Effects of an enhanced recovery after surgery programme on emergency surgical patients. ANZ J Surg. 2016; 86(11):883-888. doi: 10.1111/ans.13465. Epub 2016 Mar 17.

7. Paduraru M, Ponchietti L, Martinez Casas I, Zago M. Enhanced recovery after emergency surgery: a systematic review. Bulletin of Emergency and Trauma. 2017;2(5):70-78.

8. Rumstadt B, Guenther N, Wendling P, Engemann R, Germer C, Schmid M et al. Multimodal perioperative rehabilitation for colonic surgery in the elderly. World J Surg. 2009;33(8):1757-63. doi: 10.1007/s00268-009-0018-2.

9. Compagna R, Aprea G, De Rosa D, Gentile M, Cestaro G, Vigliotti G et al. Fast track for elderly patients: Is it feasible for colorectal surgery? International Journal of Surgery. 2014;12:S20-S22.

10. Rangel E, Cooper Z, Olufajo 0, Reznor G, Lipsitz S, Salim A et al. Mortality after emergency surgery continues to rise after discharge in the elderly: Predictors of 1-year mortality. J Trauma Acute Care Surg. 2015;79(3):349-58. doi: 10.1097/TA.0000000000000773.

11. Watters JM. Surgery in the elderly. Can J Surg. 2002;45(2):104-8.

12. Torrance AD, Powell SL, Griffiths EA. Emergency surgery in the elderly: challenges and solutions. Open Access Emerg Med. 2015; 7:55-68. doi: 10.2147/0AEM.S68324. eCollection 2015.

13. Martino A, De Martino C, Maharajan G, Evangelista M, Giamattei R, Pisapia A. Emergency Surgery in the elderly patient. BMC Geriatrics. 2011;11(Suppl 1):A30.

14. Paduraru M, Ponchietti L, Martinez Casas I, Pereira J, Landaluce A,
Ugarte B et al. Enhanced recovery after surgery (ERAS) - the evidence in geriatric emergency surgery: a systematic review. Chirurgia (Bucur). 2017;112(5):546-57.

15. Park SY, Chung JS, Kim SH, Kim YW, Ryu H, Kim DH. The safety and prognostic factors for mortality in extremely elderly patients undergoing an emergency operation. Surg Today. 2016;46(2):241-7. doi: 10.1007/s00595-015-1147-x. Epub 2015 Mar 19.

16. Peden C. Emergency surgery in the elderly patient: a quality improvement approach. Anaesthesia. 2011;66(6):440-5. doi: 10.1111/j.1365-2044.2011.06769.x.

17. Hardin RE1, Le Jemtel T, Zenilman ME. Experiences with dedicated geriatric surgical consult services: meeting the need for surgery in the frail elderly. Clin Interv Aging. 2009;4:73-80. Epub 2009 May 14.

18. de Stampa M, Vedel I, Trouvé H, Ankri J, Jean O, Somme D. Multidisciplinary teams of case managers in the implementation of an innovative integrated services delivery for the elderly in France. BMC Health Serv Res. 2014;14:159. doi: 10.1186/1472-6963-14-159.

19. Carpenter CR, Platts-Mills TF. Evolving prehospital, emergency department, and "inpatient" management models for geriatric emergencies. Clin Geriatr Med. 2013;29(1):31-47.

20. Comprehensive Assessment of the Frail Older Patient - British Geriatrics Society [Internet]. Bgs.org.uk. 2017 [cited 15 July 2017]. Available from: http://www.bgs.org.uk/index.php?option=com_content\&view= article\&id=195: gpgcgassessment\&catid=12\&ltemid=1241\&tmpl=com ponent\&print=1\&layout=default\&page=

21. Ellis G, Marshall T, Ritchie C. Comprehensive geriatric assessment in the emergency department. Clin Interv Aging. 2014;9:2033-43. doi: 10.2147/CIA.S29662. eCollection 2014

22. Ellis G, Whitehead M, Robinson D, O'Neill D, Langhorne P. Comprehensive geriatric assessment for older adults admitted to hospital: meta-analysis of randomised controlled trials. BMJ. 2011;343(oct27 1):d6553-d6553.

23. Chow WB, Rosenthal RA, Merkow RP, Ko CY, Esnaola NF. Optimal preoperative assessment of the geriatric surgical patient: a best practices guideline from the American College of Surgeons National Surgical Quality Improvement Program and the American Geriatrics Society. J Am Coll Surg. 2012;215(4):453-66.

24. Joseph B, Zangbar B, Pandit V, Fain M, Mohler MJ, Kulvatunyou N et al. Emergency General Surgery in the Elderly: Too Old or Too Frail? J Am Coll Surg. 2016;222(5):805-13. doi: 10.1016/j.jamcollsurg.2016.01.063. Epub 2016 Feb 26.

25. Searle S, Mitnitski A, Gahbauer E, Gill T, Rockwood K. A standard procedure for creating a frailty index. BMC Geriatr. 2008;8:24. doi: 10.1186/1471-2318-8-24.

26. Dunn GP. Shared decision-making for the elderly patient with a surgical condition. Br J Surg. 2016;103(2):e19-20. doi: 10.1002/ bjs.10076. Epub 2015 Dec 15.

27. Beech F, Brown A, Dhesi J, Foo I, Goodall J, Harrop-Griffiths W et al. Peri-operative care of the elderly 2014. Anaesthesia. 2014;69 Suppl 1:81-98. doi: 10.1111/anae.12524.

28. Dodds C, Foo I, Jones K, Singh S, Waldmann C. Peri-operative care of elderly patients - an urgent need for change: a consensus statement to provide guidance for specialist and non-specialist anaesthetists. Perioper Med (Lond). 2013;2(1):6. doi: 10.1186/2047-0525-2-6.

29. Parks RM, Rostoft S, Ommundsen N, Cheung KL. Peri-Operative Management of Older Adults with Cancer-The Roles of the Surgeon and Geriatrician. Cancers (Basel). 2015;7(3):1605-21.

30. Ghaferi AA, Dimick JB. Importance of teamwork, communication and culture on failure-to-rescue in the elderly. Br J Surg. 2016; 103(2):e47-51. doi: 10.1002/bjs.10031. Epub 2015 Nov 30.

31. Pearce L, Bunni J, McCarthy K, Hewitt J. Surgery in the older person: Training needs for the provision of multidisciplinary care. Ann R Coll Surg Engl. 2016;98(6):367-70.

32. Azim A, Rhee P, Haider A, Afzal H, O'Keeffe T, Gries L et al. Score to Predict Failure-to-Rescue in Geriatric Emergency General Surgery Patients. Journal of the American College of Surgeons. 2016;223(4):S54. 